\title{
ANALISIS KENDALA PEMBELAJARAN DARING PAUD DAN SD DENGAN PENDEKATAN INTERPRETATIVE STRUCTURAL MODELING
}

\author{
Casnan $^{1}$, Purnawan ${ }^{2}$, Heti Triwahyuni ${ }^{1}$, Evan Farhan Wahyu Fuadi ${ }^{1}$, Irman Firmansyah ${ }^{3}$, \\ STKIP Muhammadiyah Kuningan ${ }^{1}$, Universitas Ahmad Dahlan ${ }^{2}$, System Dynamics Center ${ }^{3}$ \\ Email: casnan@upmk.ac.id ${ }^{1}$, purnawan.purnawan@pvto.uad.ac.id ${ }^{2}$, triwahyuniheti@upmk.ac.id ${ }^{1}$ \\ evanfarhanwahyupuadi@upmk.ac.id²,irman_f@yahoo.com ${ }^{3}$ \\ Casnan. Purnawan. Heti Triwahyuni, Evan Farhan Wahyu Puadi, Firmansyah Irman. (2021). Analisis \\ Kendala Pembelajaran Daring PAUD dan SD di Kabupaten Kuningan Pendekatan Interpretative \\ Structural Modeling (ISM). Jurnal Pelita PAUD, 6(1), 33-40. \\ doi: https://doi.org/10.33222/pelitapaud.v6i1.1422
}

\begin{abstract}
Abstrak: Pembelajaran daring merupakan pembelajaran yang menggunakan model interaktif berbasis internet. Pembelajaran daring adalah program untuk mengatur kelas belajar di jaringan untuk mencapai kelompok dengan jangkauan yang lebih, analisis kendala pembelajaran daring pada Pendidikan Anak Usia Dini (PAUD) dan Sekolah Dasar (SD) bertujuan untuk membuat prioritas kendala pembelajaran daring dan mencari solusi dari permasalahan tersebut. Metode penelitian yang digunakan dalam penelitian ini adalah metode penelitian deskriptif kualitatif menggunakan sofware Interpretative Structural Modelling (ISM). Interpretative Structural Modelling (ISM) merupakan salah satu metode yang baik dalam menstrukturkan hingga mendesain hirarki permasalahan yang bersifat abstrak dan kualitatif serta dapat menggambarkan pemetaan masalah dalam bentuk kuadran dan strukturisasi masalah sesuai dengan prioritas permasalahan. Berdasarkan hasil penelitian kendala utama dalam proses pembelajaran daring adalah komunikasi, gagap teknologi dan motivasi belajar.

Kata kunci: Interpretative Structural Modeling (ISM), pembelajaran daring, PAUD, SD.

Abstract: Online learning is learning that uses an internet-based interactive model. Online learning is a program to organize learning classes on the network to reach groups with more reach, analysis of online learning constraints in Early Childhood Education (PAUD) and Elementary Schools (SD) aims to prioritize online learning obstacles and find solutions to these problems. The research method used in this research is descriptive qualitative research method using Interpretative Structural Modeling (ISM) software. Interpretative Structural Modeling (ISM) is a good method of structuring and designing a hierarchical problem that is abstract and qualitative in nature and can describe problem mapping in the form of quadrants and problem structuring according to problem priorities. Based on the research results, the main obstacles in the online learning process are communication, technology stuttering and learning motivation.
\end{abstract}

Keywords: ISM, online learning, PAUD, SD 


\section{PENDAHULUAN}

Saat ini, dunia tengah terkena wabah virus corona atau Covid-19. Coronavirus adalah virus yang menimbulkan penyakit baru dan belum pernah diidentifikasi sebelumnya pada manusia. Covid-19 mempengaruhi gejala pernapasan seperti demam, batuk, dan sesak napas. Periode inkubasi virus ini rata-rata adalah 5-6 hari dengan periode inkubasi terpanjang 14 hari. Pada tanggal 30 Januari 2020 ditetapkan sebagai darurat kesehatan dunia (Firmansyah et al, 2020:4).

Dengan adanya virus Covid-19 di dunia termasuk Indonesia tentu memberikan dampak terhadap berbagai aspek kehidupan, salah satunya dunia pendidikan. Pemerintah mengeluarkan kebijakan (Kemdikbud) yakni Surat Edaran No 4 tahun 2020 tentang pelaksanaan kebijakan pendidikan di masa darurat Covid-19, dalam surat edaran dijelaskan bahwa proses pembelajaran dilakukan di rumah melalui pembelajaran online/jarak jauh. Upaya pembelajaran daring semata-mata sebagai pencegahan menyebar secara cepat virus Covid-19 terhadap anakanak sekolah yang secara usia lebih rentan terkena penyakit (Yurianto dalam Dewi, 2020:56). Kebijakan ini merubah kegiatan belajar mengajar tatap muka menjadi daring. Pemerintah mengganti sistem pembelajaran melalui aplikasi pembelajaran daring yang ada. Dengan adanya kebijakan ini, pembelajaran daring yang sebelumnya masih tidak maksimal diterapkan menjadi satusatunya pilihan bentuk pembelajaran (Syarifudin, 2020:32; Basar et al., 2021:213; Asmuni, 2020:283).

Pembelajaran daring adalah pembelajaran yang menggunakan model interaktif berbasis internet. Pembelajaran daring adalah program untuk mengatur kelas belajar di jaringan untuk mencapai kelompok dengan jangkauan yang lebih (Bildaqih dan Qomaruddin dalam Asmuni, 2020:283). Menurut Isman (Dewi, 2020:6), pembelajaran daring adalah penggunaan jaringan internet dalam proses pembelajaran. Dengan pembelajaran online siswa memiliki kebebasan waktu belajar, dapat belajar kapan saja dan di mana saja. Siswa dapat berinteraksi dengan guru menggunakan beberapa aplikasi seperti clasroom, konverensi video, telepon atau obrolan langsung zoom dan melalui grup WhatsApp. Pembelajaran daring adalah inovasi untuk menjawab tantangan ketersediaan sumber daya belajar yang bervariasi. Keberhasilan model atau media pembelajaran tergantung pada karakteristik setiap siswa. Sebagaimana diungkapkan oleh Nakayama (Dewi, 2020:6)bahwa pembelajaran daring tidak akan berhasil diterapkan kepada semua siswa. Dikarenakan faktor serta lingkungan siswa yang berbeda.

Pembelajaran daring memiliki kelebihan dan kekurangan. Kelebihan pembelajaran daring adalah lebih praktis dan santai, karena dapat memberikan dan pelaporan tugas setiap saat. Pembelajaran bisa lebih fleksibel dilakukan kapanpun dan dimanapun, menghemat waktu, akses pembelajaran dengan mudah, penyampaian informasi lebih cepat, memudahkan pengambilan nilai pengetahuan terutama memakai Google Form, pembelajaran bisa dipantau dan didampingi oleh orang tua masing-masing, serta guru dan siswa memperoleh pengalaman baru terkait pembelajaran daring (Anugrahana, 2020:287).

Kelebihan pembelajaran online menurut (Santika, 2020:12) adalah, tidak membutuhkan ruang kelas karena pembelajaran berlangsung secara jarak jauh. Siswa dapat menciptakan suasana belajar dengan fasilitas internet yang ada., guru tidak perlu berhadapan langsung di depan kelas, waktu yang tak terbatas dalam pembelajaran artinya dapat dilakukan kapan saja dan di mana saja. Oleh karena itu mode pembelajaran daring dapat dikatakan efisien dan efektif apabila sarana prasarana yang mendukung tersedia dengan baik.

Sedangkan kekurangan pembelajaran daring adalah keterlibatan siswa dalam proses belajar. Kebanyakan dilihat dari hasil keterlibatan siswa selama mengikuti pembelajaran daring secara penuh dari awal pembelajaran sampai akhir pembelajaran. Dari hasil penelitian menunjukkan bahwa hanya 50\% siswa yang aktif terlibat secara penuh, 33 $\%$ siswa yang terlibat aktif. Sedangkan $17 \%$ lainnya, siswa yang kurang aktif dan kurang berpartisipasi dalam pembelajaran daring (Anugrahana, 2020:287) 
Menurut (Harahap et al., 2021: 1829). kekurangan pembelajaran daring yaitu berkaitan dengan sarana prasarana, kurangnya pemahaman orang tua dan guru, ketidaksiapan guru maupun orang tua dari segi waktu, media pembelajaran, komunikasi, minat belajar, juga tehnik pemberian nilai. Tak hanya itu, komunikasi guru dan siswa berkurang, cenderungan mengabaikan aspek akademik, proses belajar dan mengajar seperti pelatihan, guru harus menguasai teknik pembelajaran dengan menggunakan ICT (Information Communication Technology), dan siswa tidak mempunyai motivasi belajar, tidak tersedianya fasilitas internet (Taufik dalam Suhery et al., 2020:130).

Selama proses pembelajaran daring, begitu banyak masalah serta kendala yang dihadapi seperti keterbatasan signal dan ketidaktersediaan fasilitas pembelajaran daring di setiap siswa. Tidak semua siswa berasal dari latar belakang keluarga mampu. Kemudian bentuk penugasan via daring dianggap sulit bagi sebagian siswa maupun orang tua. Hal ini sering terjadi pada pada tingkat sekolah dasar. Proses pembelajaran yang dijadikan solusi oleh pemerintah menimbulkan masalah sehingga kurang maksimalnya pembelajaran (Syarifudin, 2020:33).

Menurut (Basar et al., 2021:213) masalah yang dihadapi sekaligus menjadi tantangan pembelajaran daring adalah berkaitan dengan kesiapan sumber daya manusia, kurang jelasnya arahan pemerintah daerah, belum adanya kurikulum yang tepat, dan keterbatasan sarana prasarana, khususnya teknologi dan jaringan internet. Selain itu, siswa tidak termotivasi untuk belajar, dan tidak bisa menguasai pembelajaran dengan baik. Menurut (Fadilla, 2021:49) masalah dalam pelaksanaan pembelajaran daring melalui aplikasi, siswa harus memiliki smartphone sebagai alat dalam proses pembelajaran. Kemudian, untuk mengakses aplikasi harus menggunakan konéksi internet, kurangnya pengetahuan tentang teknologi bagi sebagian orang juga dapat menjadi penghambat proses pembelajaran.

Berdasarkan berbagai permasalahan yang dihadapi dalam proses pembelajaran daring, maka perlu adanya penelitian berkaitan dengan analisis permasalahan. Analisis tersebut bertujuan untuk membuat prioritas kendala pembelajaran daring dan mencari solusi dari permasalahan yang terjadi. Analisis permasalahan terkait pembelajaran daring menggunakan menggunakan sofware Interpretative Structural Modelling (ISM) yang merupakan salah satu metode dalam menstrukturkan hingga mendesain hirarki akar masalah yang bersifat abstrak dan kualitatif. ISM diperkenalkan pertama kali oleh Warfield pada tahun 1974. ISM merupakan metode yang digunakan di berbagai bidang (Mishra dalam Arsiwi \& Adi, 2020:28). ISM adalah alat analisis sebagai pendukung keputusan yang memfasilitasi pemahaman secara menyeluruh dalam situasi kompleks dengan mengkaitkan dan mengorganisir gagasan dalam melalui peta visual (Darmawan, 2017:2). ISM adalah sebuah metodologi perencanaan yang digunakan untuk mengidentifikasi dan menyimpulkan hubungan faktor dalam sebuah permasalahan (Sage dalam Rusydiana, 2018: 5). Permasalahan proses pembelajaran daring selama masa pandemi cukup banyak sehingga perlu memprioritaskan kendala tersebut untuk mencari strategi-strategi prioritas. ISM dapat digunakan untuk menganalisis kendala pembelajaran daring di Pendidikan Anak Usia Dini (PAUD) dan Sekolah Dasar (SD).

\section{METODE PENELITIAN}

Metode yang digunakan dalam penelitian ini adalah kualitatif deskriptif yang merupakan penelitian yang berkaitan dengan ide, persepsi, pendapat, kepercayaan yang akan diteliti dan tidak dapat di ukur dengan angka.

Waktu pelaksanaan penelitian berlangsung selama 3 bulan pada sekolah tingkat PAUD dan SD yang berada di Kabupaten Kuningan. Tehnik pengambilan sampel berdasarkan random sampling yaitu pengambilan sampel penelitian yang digunakan dengan acak sederhana. Tahapan penelitian ini meliputi membangun kerangka konseptual, merumuskan permasalahan, pemilihan sampel instrumentasi, pengumpulan data, analisis data, pengujian dan kesimpulan. 
P ISSN 2548-6284 E ISSN 2615-0360

Vol. 6 No. 1 Desember 2021

Tehnik pengumpulan data menggunakan tehnik observasi dan wawancara terhadap responden yang ditentukan dari sampel. Kemudian data dianalisis menggunakan software Interpretative Structural Modelling (ISM) yang merupakan aplikasi sistematis dari teori grafik elementer, yang digunakan untuk menjelaskan hubungan konseptual antar elemen. ISM adalah representasi (digraph) hubungan dan klasifikasi persoalan yang rumit dalam suatu rangkaian terstruktur.

ISM digunakan untuk menentukan faktor penggerak dalam skenario kebijakan dan digunakan untuk menggambarkan permasalahan yang bersifat abstrak sehingga dapat lebih terstruktur. Tahapan yang dilakukan adalah dengan menginventarisasi kendala pembelajaran daring di Pindidikan Anak Usia Dini (PAUD) dan Sekolah Dasar (SD).

Kendala yang telah tersusun, tahap selanjutnya adalah memberikan penilaian perbandingan dengan VAXO. Simbol VAXO digunakan untuk menggambarkan hubungan kontekstual antar dua variabel. Simbol V untuk hubungan dari $\mathrm{i}$ ke $\mathrm{j}$ tetapi tidak untuk kedua arah, A untuk hubungan dari $\mathrm{j}$ ke $\mathrm{i}$ tetapi tidak untuk kedua arah, $\mathrm{X}$ untuk kedua arah, hubungan dari i ke j dan j ke i, O jika tidak muncul hubungan yang valid antara variabel. Analisis terhadap output ISM berupa pemetaan permasalahan dan strukturisasi permasalahan dengan syarat hasil analisis tersebut telah konsisten. Skenario kendala dominan dilihat sebagai alternatif masukan dalam kebijakan dan strategi. Tahapan analisis ISM dalam penelitian ini seperti pada Gambar 1.

Analisis ISM dapat memetakan dan menstrukturkan permasalahan yang bersifat abstrak menjadi lebih mudah dipahami tetapi pemahaman terhadap penilaian dengan VAXO perlu diperhatikan secara seksama dalam menilainya. Tahapan dalam melakukan ISM dibagi menjadi dua bagian, yaitu Penyusunan Hirarki dan Klasifikasi subelemen.

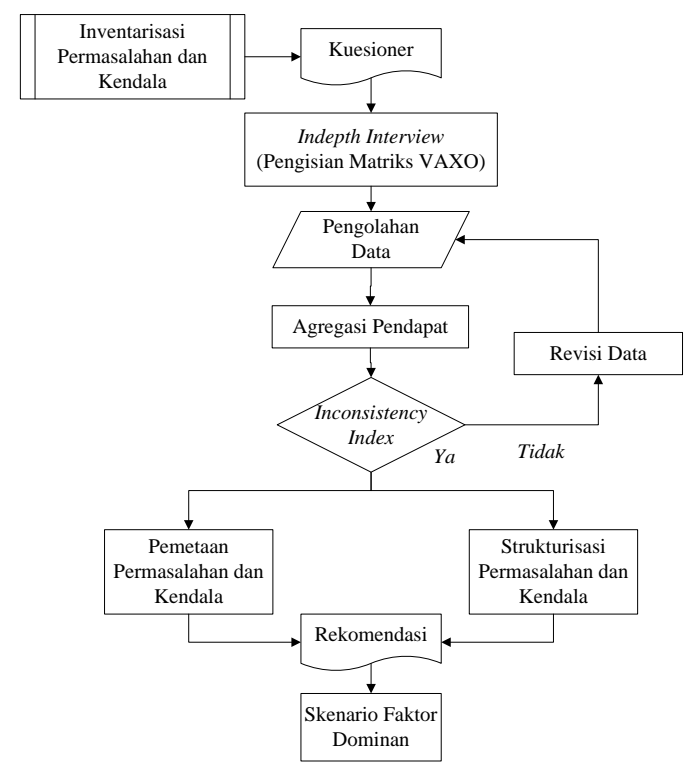

Gambar 1 Tahapan analisis ISM dalam strukturisasi kendala penerapan strategi

Tahapan Penyusunan Hirarki dan Klasifikasi subelemen adalah sebagai berikut:

\section{Penyusunan Hirarki}

Program yang sedang ditelaah dibagi menjadi elemen-elemen di mana setiap elemen selanjutnya diuraikan menjadi sejumlah subelemen.

Menentapkan hubungan kontekstual antara subelemen yang terkandung adanya suatu pengarahan (direction) dalam terminologi subordinat yang menuju pada perbandingan berpasangan (oleh pakar atau responden). Jika jumlah pakar lebih dari satu maka dilakukan perataan. Penilaian hubungan kontekstual pada matriks perbandingan berpasangan menggunakan simbol:

$\mathrm{V}$ jika $\mathrm{e}_{\mathrm{ij}}=1$ dan $\mathrm{e}_{\mathrm{ji}}=0 ; \mathrm{V}=$ subelemen ke-i harus lebih dulu ditangani dibandingkan subelemen ke-j

A jika $e_{i j}=0$ dan $e_{j i}=1 ; A=$ subelemen ke-j harus lebih dulu ditangani dibandingkan subelemen ke-i

$\mathrm{X}$ jika $\mathrm{e}_{\mathrm{ij}}=1$ dan $\mathrm{e}_{\mathrm{ji}}=1 ; \mathrm{X}=$ kedua subelemen harus ditangani bersama

$\mathrm{O} j \mathrm{jka} \mathrm{e}_{\mathrm{ij}}=0$ dan $\mathrm{e}_{\mathrm{ji}}=0 ; \mathrm{O}=$ kedua subelemen bukan prioritas

Pengertian nilai $\mathrm{e}_{\mathrm{ij}}=1$ adalah ada hubungan kontekstual antara subelemen ke-i dan ke-j, sedangkan nilai $\mathrm{e}_{\mathrm{ji}}=0$ adalah tidak ada hubungan kontekstual antara subelemen ke-i dan ke-j.

Hasil olahan tersebut tersusun dalam structural self interaction matrix (SSIM). 
SSIM dibuat dalam bentuk tabel reachability matrix (RM) dengan mengganti $\mathrm{V}, \mathrm{A}, \mathrm{X}$ dan O menjadi bilangan 1 dan 0.

Setelah Structural self interaction matrix (SSIM) terisi sesuai pendapat responden, maka simbol (V, A, X, O) dapat digantikan dengan simbol (1 dan 0$)$ dengan ketentuan yang ada sehingga dapat diketahui nilai dari hasil reachability matrix $(\mathrm{RM})$ final elemen.

Dengan menjumlahkan nilai subelemen secara horizontal; untuk nilai rangking ditentukan berdasarkan nilai dari driver power yang diurutkan mulai dari yang terbesar sampai yang terkecil; nilai dependence diperoleh dari penjumlahan nilai subelemen secara vertikal; untuk nilai level ditentukan berdasarkan nilai dari dependence yang diurutkan mulai dari yang terbesar sampai yang terkecil. Tahapan dan proses dalam melakukan teknik ISM.

Klasifikasi subelemen

Secara garis besar klasifikasi subelemen digolongkan dalam 4 sektor yaitu:

Sektor 1; weak driver-weak dependent variabels (Autonomous). Subelemen yang masuk dalam sektor ini umumnya tidak berkaitan dengan sistem, dan mungkin mempunyai hubungan sedikit, meskipun hubungan tersebut bisa saja kuat. Subelemen yang masuk pada sektor 1 jika:Nilai $\mathrm{DP} \leq 0,5$ $\mathrm{X}$ dan nilai $\mathrm{D} \leq 0,5 \mathrm{X}, \mathrm{X}$ adalah jumlah subelemen.

Sektor 2; weak driver-strongly dependent variabels (Dependent). Umumnya subelemen yang masuk dalam sektor ini adalah subelemen yang tidak bebas. Subelemen yang masuk pada sektor 2 jika: Nilai DP $\leq 0,5 \mathrm{X}$ dan nilai $\mathrm{D}>0,5 \mathrm{X}, \mathrm{X}$ adalah jumlah subelemen.

Sektor 3; strong driver- strongly dependent variabels (Linkage). Subelemen yang masuk dalam sektor ini harus dikaji secara hati-hati, sebab hubungan antara elemen tidak stabil. Setiap tindakan pada subelemen akan memberikan dampak terhadap subelemen lainnya dan pengaruh umpan baliknya dapat memperbesar dampak. Subelemen yang masuk pada sektor 3 jika: Nilai DP > 0,5 X dan nilai $\mathrm{D}>0,5 \mathrm{X}, \mathrm{X}$ adalah jumlah subelemen.

Sektor 4; strong driver-weak dependent variabels (Independent). Subelemen yang masuk dalam sektor ini merupakan bagian sisa dari sistem dan disebut peubah bebas.
Subelemen yang masuk pada sektor 4 jika: Nilai DP $>0,5 \mathrm{X}$ dan nilai $\mathrm{D} \leq 0,5 \mathrm{X}, \mathrm{X}$ adalah jumlah subelemen.

Analisa matrik dari klasifikasi subelemen disajikan pada Gambar 2.

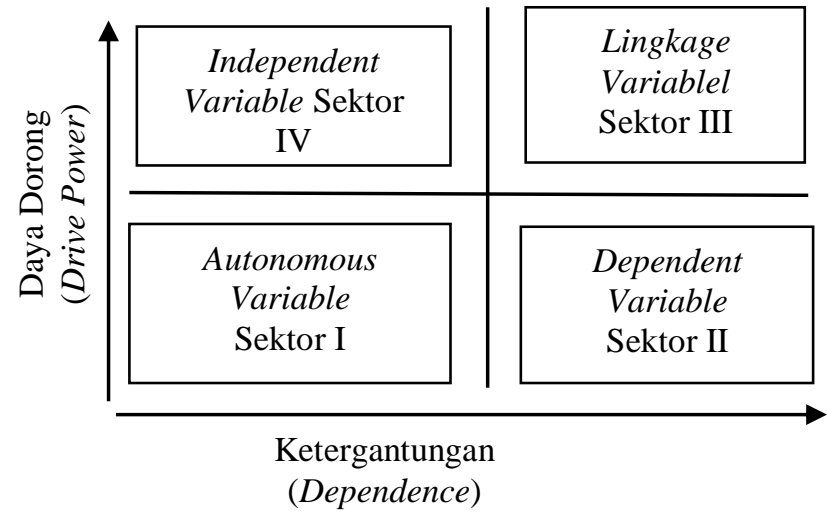

Gambar 2 Tingkat pengaruh dan ketergantungan antar faktor

\section{HASIL PENELITIAN DAN PEMBAHASAN}

Berdasarkan hasil observasi dan wawancara sampel yang sudah ditentukan, mendapatkan data 9 variabel yang menjadi faktor kendala pembelajaran daring yaitu komunikasi, metode pembelajaran, materi atau media pembelajaran, kuota/biaya internet, gagap teknologi, motivasi belajar, waktu pendampingan, kesabaran orang tua, dan fasilitas pendukung.

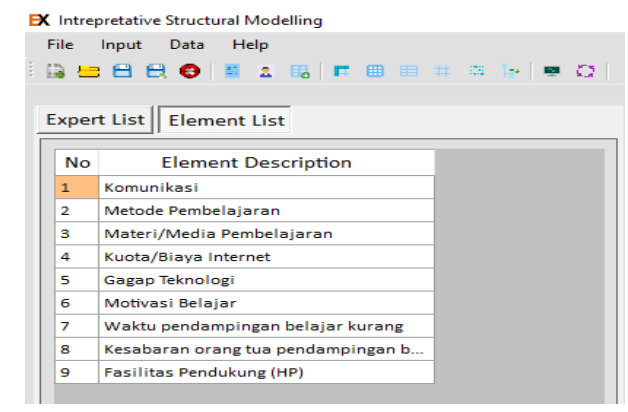

Gambar 3 Variabel Kendala Pembelajaran

Selanjutnya, yang dilakukan dalam analisis penelitian ini yaitu membuat Structural SelfInteraction Matrix (SSIM), yang terdapat empat simbol baku digunakan untuk menggambarkan hubungan variabel yang menjadi kendala proses pembelajaran daring 
di PAUD dan SD. Empat simbol baku adalah VAXO sesuai dengan hasil observasi dan wawancara yang diinput ke dalam Software ISM. Hasil dari SSIM dilihat dalam gambar 4.

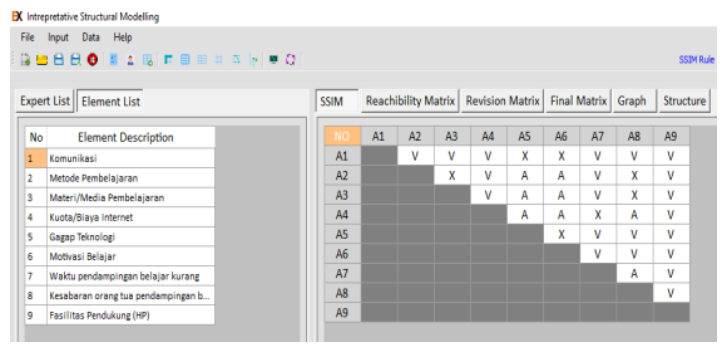

Gambar 4 Structural Self Interaction Matrix (SSIM)

Berikutnya analisis yang dilakukan adalah Reachability Matrix, pada tahap ini simbol VAXO pada tabel SSIM diubah menjadi angka "1" dan "0" yang menyatakan hubungan antar satu faktor dengan faktor lainnya.

Aturan untuk merubah simbol VAXO apada angka adalah sebagai berikut.

Jika entri ( $i, j$ ) dalam SSIM adalah V, maka entri ( $i, j$ ) dalam reachability matrix menjadi 1 dan entri (j, i) menjadi 0 .

Jika entri ( $i, j$ ) dalam SSIM adalah A, maka entri $(i, j)$ dalam matriks menjadi 0 dan entri (j, i ) menjadi 1 .

Jika entri ( $i, j$ ) dalam SSIM adalah X, maka entri ( $i, j$ ) dalam matriks menjadi 1 dan entri (j, i ) menjadi 1.

Jika entri ( $i, j$ ) dalam SSIM adalah O , maka entri ( $i, j$ ) dalam matriks menjadi 0 dan entri (j, i ) menjadi 0 .

Mengikuti aturan-aturan ini, initial Reachability Matrix disiapkan. Entri 1* dimasukkan untuk menyertakan transitivitas guna mengisi kesenjangan (jika ada) dalam pengumpulan opini selama pengembangan Structural Self-Instructional Matrix (SSIM). Setelah menyertakan konsep transitivitas, diperoleh final Reachability Matrix (Darmawan, 2017:40).

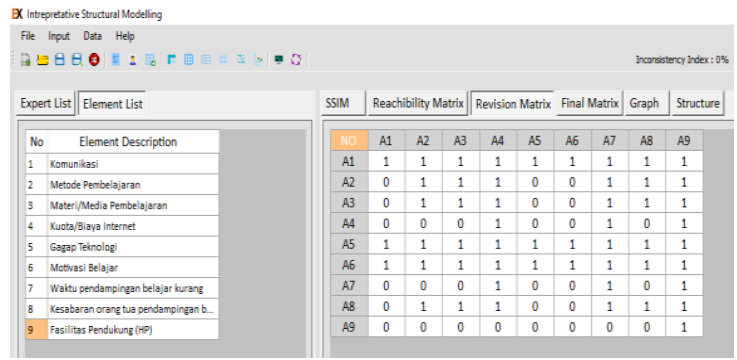

melalui kuadran MICMAC. Dasar dari klasifikasi ini adalah driving power dan dependence power dihitung dalam matriks reachibility akhir atau final. Selain itu, analisis MICMAC digunakan untuk memeriksa hubungan langsung antara variabel yang diperoleh dari teknik ISM. Ada empat kelompok klasifikasi yang dapat dilihat pada gambar 6.

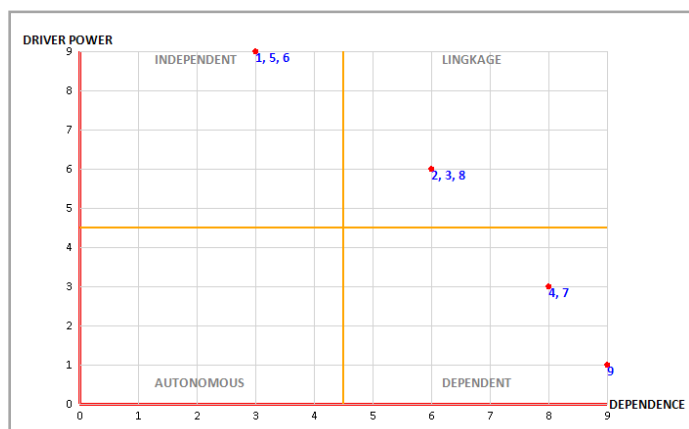

Gambar 6. Klasifikasi Kendala Pembelajaran Daring di PAUD dan SD

Dapat dijelaskan bahwa empat kelompok dalam klasifikasi tersebut adalah

Variabel Autonomous: Variabel-variabel ini tidak memiliki daya pengaruh tinggi. Dalam klasifikasi ini tidak ada yang masuk sebagai faktor kendala pembelajaran daring di PAUD dan SD

Variabel Dependent: Kuadran II merupakan variabel dependen yang memiliki kekuatan mempengaruhi secara rendah dan ketergantungan tinggi. Dari analisis MICMAC, kendala pembelajaran daring PAUD dan SD yaitu 4, 7, 9 (kuota, waktu pendampingan, dan fasilitas pendukung) sebagai variabel dependent.

Variabel Linkage: Variabel ini memiliki daya pengaruh yang tinggi sekaligus ketergantungan yang tinggi pula. Cirinya adalah setiap tindakan yang dilakukan memberikan efek pada variabel di atas tingkat mereka dan efek umpan balik pada diri mereka sendiri. Yang termasuk dalam kategori variabel linkage adalah 2, 3, 8 (metode, materi/media, dan kesabaran orang tua).

Variabel Independent: Variabel-variabel ini memiliki daya pengaruh yang tinggi dan tingkat ketergantungan yang rendah. Dalam penelitian ini angka 1, 5, 6 (komunikasi, gagap teknologi, dan motivasi belajar) termasuk dalam kategori ini. 
P ISSN 2548-6284 E ISSN 2615-0360

Vol. 6 No. 1 Desember 2021

Tahap analisis berikutnya yaitu hasil Reachibility Matrix dibagi secara terstruktur berdasarkan level yang telah ditentukan. Pada gambar 6. menunjukkan bahwa arah panah keatas memiliki arti faktor tersebut menghasilkan faktor diatasnya, sedangkan arah panah ke samping memiliki arti saling mempengaruhi dalam menghasilkan faktor diatasnya (Attri et al., 2013).

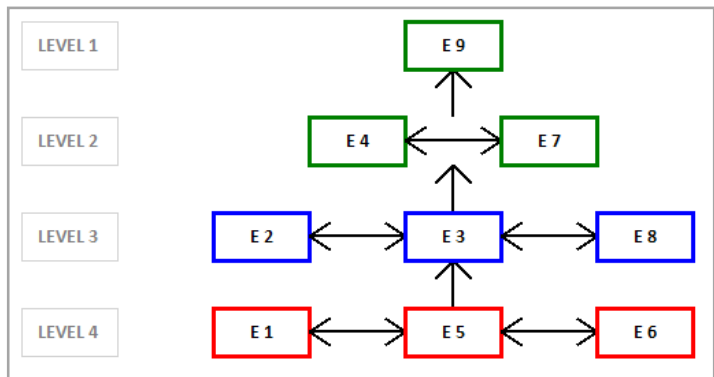

Gambar 7. Strukturisasi Kendala Pembelajaran Daring di PAUD dan SD

Dari gambar 7 dapat menunjukan bahwa yang menjadi faktor penting kendala pembelajaran daring PAUD dan SD yaitu komunikasi, gagap teknologi, dan motivasi belajar. Komunikasi dalam proses belajar daring sering terjadi seperti halnya diintervensi noise atau gangguan teknis yang menyebabkan kesalahpahaman antara guru dan siswa. Salah satunya memunculkan pemikiran pada siswa bahwa mereka dinilai secara negatif oleh pengajarnya (Delwiche dan Henderson dalam Fadhal et al., 2020:276)

Faktor kendala dalam sebuah komunikasi adalah kejenuhan yang tinggi baik siswa maupun pendidik dalam situasi kaku dan formal. Komunikasi cenderung hanya satu arah, adanya ketidaknyamanan akibat proses komunikasi melalui video conference seperti zoom, google meet, dan sebagainya. Kesan komunikasi dalam proses pembelajaran daring cenderung resmi, formal, dan serius. Lalu permasalahan komunikasi sering terjadi akibat fasilitas penunjang komunikasi mengalami gangguan maupun hambatan. Kelelahan serta emosi yang tidak stabil ditengah pandemi menjadi faktor kendala yang cukup tinggi dalam proses pembelajaran daring (Fadhal et al., 2020:280). Agar terciptanya komunikasi yang baik, maka guru dan juga siswa harus bisa mempersiapkan moda pembelajaran secara matang (mengecek koneksi, alat microphone), juga selaku guru membuat suasana yang menyenangkan dalam proses berlangsungnya kelas secara daring.

Faktor penting kendala pembelajaran daring selanjutnya adalah gagap teknologi. Keberadaan teknologi kini menjadi bagian yang sangat berpengaruh pada dunia pendidikan. Menurut Triwiyanto (Asiba, 2020:2), menyebutkan bahwa pendidikan adalah usaha memberikan pengalaman belajar secara terprogram dalam bentuk pendidikan formal, nonformal, dan informal di sekolah, dan luar sekolah. Guru memiliki peranan yang penting dalam pelaksanaan pembelajaran, oleh karena itu pengetahuan, keterampilan serta penguasaan teknologi informasi dan komunikasi sangatlah penting dimiliki dimasa saat ini (Tekege dalam Asiba, 2020:3).

Kendala teknologi juga dihadapi para orang tua sebagai pendamping pembelajaran. Tidak semua orang tua mampu mengoperasikan gadget maupun laptop karena ada beberapa orang tua yang keadaanya masih belum melek teknologi (Lestari \& Gunawan dalam Wardani \& Ayriza, 2021:777). Penguasaan teknologi yang rendah merupakan kendala yang paling sering ditemui dalam pembelajaran daring. Solusi dari permasalah terkait kurangnya penguasaan teknologi, khususnya bagi guru bisa dilakukan pelatihan terkait pemakaian aplikasi pembelajaran daring serta hal yang berkaitan dengan teknologi. Sedangkan bagi para orang tua siswa, penugasan secara pesan pendek (singkat) bisa menjadi solusi agar mempermudah bimbingan serta pembelajaran yang dilakukan.

Faktor kendala yang ketiga adalah motivasi belajar. Motibvasi belajar siswa kini menjadi menurun, penurunanya disebabkan karena pembelajaran yang membosankan. Jika dulu pembelajaran tatap muka dapat memberikan motivasi karena dapat berdiskusi secara langsung terkait pembelajaran, bertemu dengan teman-teman (Hafida, et al., 2020:30). Motivasi ini dapat ditingkatkan jika guru mampu berinovasi dalam pembelajaran sehingga para siswa tidak terbebani dengan adanya tugas serta pembelajaran yang hanya dilakukan secara komunikasi virtual. 


\section{SIMPULAN}

Berdasarkan hasil analisis, kendala utama dalam proses pembelajaran daring di PAUD dan SD Kabupatén Kuningan adalah komunikasi, gagap teknologi, juga motivasi belajar. Permasalahan komunikasi dapat diatasi dengan persiapan media penunjang sebelum kegiatan belajar, gagap teknologi dapat diatasi dengan berbagai pelatihan juga penugasan yang diberikan melalui bimbingan orang tua melalui pesan singkat, sedangkan faktor motivasi dapat diatasi dengan kemampuan guru yang kreatif dalam berinovasi disetiap proses belajar daring berlangsung.

\section{DAFTAR PUSTAKA}

Anugrahana, A. (2020). Hambatan, Solusi dan Harapan: Pembelajaran Daring Selama Masa Pandemi Covid-19 Oleh Guru Sekolah Dasar. Scholaria: Jurnal Pendidikan dan Kebudayaan, 10(3), 282-289. https://doi.org/10.24246/j.js.2020.v10.i3.p28 2-289

Arsiwi, P., \& Adi, P. W. (2020). Interpretive Structural Modelling Untuk Meningkatkan Daya Saing Rantai Pasok UKM Mina Indo Sejahtera. Jurnal PASTI, 14(1), 26-36. https://doi.org/10.22441/pasti.2020.v14i1.00 3

Asiba, W. P. (2020). Pentingnya Teknologi Bagi Guru Pada Masa Pandemi Covid 19. 8.

Asmuni. (2020). Problematika Pembelajaran Daring di Masa Pandemi Covid-19 dan Solusi Pemecahannya. 7(4), 281-288.

Basar, A. M., Islam, P. A., Nurul, S., Cikarang, F., \& Bekasi, B. (2021). Problematika Pembelajaran Jarak Jauh Pada Masa Pandemi Covid-19 ( Studi Kasus di SMPIT Nurul Fajri-Cikarang Barat-Bekasi) A . Pendahuluan kemampuan, sikap, dan bentuk-bentuk tingkah laku yang bernilai positif. Hal itu untuk pencipta . Pendidikan s. 2(1), 208-218.

Darmawan, D. P. (2017). Interpretative Structural Modelling. Penerbit Elmatera, 116.

Dewi, W. A. F. (2020). Dampak COVID-19 terhadap Implementasi Pembelajaran Daring di Sekolah Dasar. Edukatif: Jurnal Ilmu Pendidikan, 2(1), 55-61. https://doi.org/10.31004/edukatif.v2i1.89

Fadhal, S., Al, U., \& Indonesia, A. (2020). Hambatan Komunikasi dan Budaya dalam
Pembelajaran Daring pada Masa Pandemi COVID-19. 273-290.

Fadilla, A. N. (2021). Problematika Pembelajaran Matematika Daring di Masa Pandemi Covid19. Jurnal Jendela Pendidikan, 01(02), 4860.

Firmansyah, I., Pramudya, B., Sadikin, P. (2020). System Dynamics of Peak Projection Covid19 In Indonesia. Journal of System Dynamics, 01(01), 1-8.

Hafida, Lilih, Wilanika, Ludi, S. (2020). Penurunan Motivasi dan Keaktifan Belajar Siswa selama Pembelajaran Daring di Tengah Pandemi Covid-19.

Harahap, S. A., Dimyati, D., \& Purwanta, E. (2021). Problematika Pembelajaran Daring dan Luring Anak Usia Dini bagi Guru dan Orang tua di Masa Pandemi Covid 19. Jurnal Obsesi: Jurnal Pendidikan Anak Usia Dini, 5(2), 1825-1836. https://doi.org/10.31004/obsesi.v5i2.1013

Rusydiana, A. S. (2018). Aplikasi Interpretive Structural Modeling untuk Strategi Pengembangan Wakaf Tunai di Indonesia. Jurnal Ekonomi dan Bisnis Is, 4(1), 1-17.

Santika, I. W. E. (2020). Pendidikan Karakter pada Pembelajaran Daring. Indonesian Values and Character Education Journal, 3(1), 8-19.

Suhery, Putra, T. J., \& Jasmalinda. (2020). Sosialisasi Penggunaan Aplikasi Zoom Meeting dan Google Classroom pada Guru di SDN 17 MATA AIR PADANG SELATAN. Jurnal Inovasi Pendidikan, 1(3), $1-4$.

Syarifudin, A. S. (2020). Impelementasi Pembelajaran Daring Untuk Meningkatkan Mutu Pendidikan Sebagai Dampak Diterapkannya Social Distancing. Jurnal Pendidikan Bahasa dan Sastra Indonesia Metalingua, 5(1), 31-34. https://doi.org/10.21107/metalingua.v5i1.70 72

Wardani, A., \& Ayriza, Y. (2021). Analisis Kendala Orang Tua dalam Mendampingi Anak Belajar di Rumah Pada Masa Pandemi Covid-19. 5(1), 772-782. https://doi.org/10.31004/obsesi.v5i1.705 